\title{
Online test, selvevaluering og læring - hvem hjælper vi med e-læring?
}

\author{
Helle Lykke Nielsen \\ ph.d., lektor, \\ Center for Mellemøststudier, \\ Syddansk Universitet \\ Mail: hln@language.sdu.dk \\ Web: www.humaniora.sdu.dk/middle-east
}

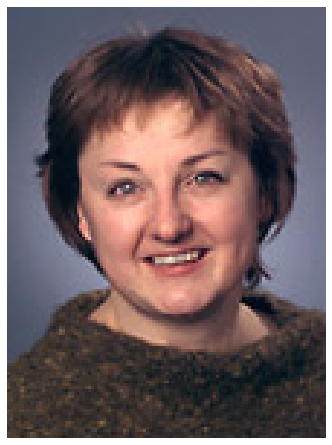

Helle Lykke Nielsen er fagansvarlig for arabiskuddannelserne ved Syddansk Universitet, hvor hun har vœret ansat siden 1986. Hun har skrevet ph.d om fremmedsprogspcedagogik og fjerne fremmedsprog, har udgivet en rcekke artikler om sprogtilegnelse af arabisk som fremmedsprog og har i de senere år arbejdet med integration af e-læringsvœrktøjer i arabiskundervisningen. Hendes forskningsmæssige fokus ligger i disse år på indvandrersprogenes omfang og betydning i Danmark, primæert med henblik på arabisk.

\section{Indledning}

Med udgangspunkt i målsætninger, målgruppe og undervisningserfaringer fra arabiskuddannelserne ved Syddansk Universitet beskriver artiklen, hvordan online test, selvevaluering og læringsplaner er blevet inddraget i undervisning for at fremme de studerendes udvikling fra elev til studerende og siden lære at tage mere ansvar for egen læring. Artiklen beskriver hvordan redskaberne er blevet integreret i universitetets e-læringsplatform, og hvilke praktiske og læringsmæssige problemer det har affødt. Artiklen konkluderer tentativt (i) at det kræver obligatorisk brug af e-læringsredskaberne, hvis man ønsker at alle studerende skal benytte dem; (ii) at køn og etnisk baggrund ser ud til at spille ind på brugen af e-læringsredskaberne; samt at (iii) de studerende, der kunne have mest gavn af at udnytte e-læringsredskaberne, er dem, der bruger dem mindst.

\section{Baggrund og læringsmål}

Arabiskuddannelserne ved Syddansk Universitet er i deres udgangspunkt anvendelsesorienterede: Det betyder i praksis at man kun kan læse arabisk i kombination med et andet fag ${ }^{1}$, p.t. enten afsætnings- og erhvervsøkonomi (cand. negot. uddannelsen) eller kommunikation. Fagene, der læses parallelt, fordeles nogenlunde ligeligt, således at ca. halvdelen af tiden bruges på sprogtilegnelse, den anden halvdel på kombinationsfaget.

For den sproglige del af uddannelserne, som er mit anliggende her, betyder det anvendelsesorienterede sigte endvidere at sprogundervisningens mål er entydigt kommunikativt: De studerende skal træne færdigheder i at lytte, tale, læse og skrive arabisk, så de opnår sproglige færdigheder, der umiddelbart kan bruges i en faglig eller social kontekst. De studerende forventes ikke at have nogen forkundskaber når de starter på uddannelserne, 3. studieår tilbringes i et arabisktalende land, hvor de følger almene sprog- og kulturkurser og er i praktik, og målet på bachelorniveau er, at de kan klare forskellige kommunikative opgaver inden for deres 
kombinationsfag på arabisk. Sproget anskues med andre ord som et redskab, kombinationsfaget som det fagområde, de studerende får deres videnskabelige træning inden for.

Det anvendelsesorienterede mål er et bevidst brud med den filologiske tradition i arabisk, der ellers hersker i andre europæiske universitetsmiljøer. Og et sådant brud har konsekvenser, både for uddannelsernes indhold og pædagogik: Ikke blot skal der laves nye fagbeskrivelser og udarbejdes hensigtsmæssige undervisningsmaterialer; der skal også gøres op med en lang tradition for sprogbeskrivelse og fokus på læsefærdighed i undervisningen og udvikles nye kompetencer, der er nødvendige i en anvendelsesorienteret sprogundervisning.

Bruddet med filologien har været befordret af et ønske om arbejdsmarkedsrelevans: Det er ganske få danske og internationale virksomheder og institutioner, der har behov for og midler til at ansætte unge, som alene er kompetente i arabisk, endsige i arabisk filologi, også selv om både globalisering og indvandring har gjort arabisk til det største indvandrersprog i Europa sammen med tyrkisk. Samtidig er arbejdsmarkedet for kandidater med arabisk karakteriseret ved manglen på veldefinerede ansættelsesområder og en strukturel sårbarhed over for de politiske og økonomiske forandringer, indvandrersprog generelt er underlagt i de vestlige samfund.

En anvendelsesorienteret uddannelse, hvis sproglige elementer eksplicit sigter mod at opfylde konkrete behov på et arbejdsmarked der er i konstant forandring, stiller særlige krav til de kompetencer, uddannelserne skal fremme: Ikke blot skal de unge som alle andre nye studerende gennem processen fra elev til studerende - altså socialiseres ind i universitetsmiljøet og gradvis lære at tage ansvar for egen læring -, så de systematisk kan tilegne sig de krav om viden, selvstændighed og analytiske færdigheder, der kendetegner en akademisk uddannelse. De skal også forberedes til et arbejdsmarked der kræver fleksibilitet og tilpasningsevne til stadigt skiftende opgaver, så de kan klare de nødvendige omstillingsprocesser. Det gælder så meget mere, som at målgruppen for vores arabiskuddannelser grundlæggende har ændret sig siden slutningen af 1990'erne: Uddannelserne der oprindelig var tænkt som et tilbud til danske gymnasielever, som gerne vil arbejde med eller i den arabiske verden, er i disse år primært befolket med arabiske andengenerationsunge, der typisk har andre sproglige og kulturelle forudsætninger, end det vi tidligere har kendt. Samtidig er karaktergennemsnittet for de studerende, der starter på uddannelserne, faldet, så vi i dag har et af SDU's laveste gennemsnit. Skal uddannelsernes overordnede mål om anvendelighed og arbejdsmarkedskompetence også fastholdes for denne gruppe, kræver det øget opmærksomhed på pædagogiske redskaber, der kan fremme de ønskede kompetencer. ${ }^{2}$

Med udgangspunkt i arabiskuddannelsernes overordnede målsætning, den ændrede målgruppe samt de erfaringer vi løbende har gjort i undervisningen, har det vist sig nødvendigt at sætte eksplicit ind på at udvikle de studerendes kompetencer inden for følgende områder:

1. Studiekompetence: Processen fra elev til studerende skal understøttes, så vi sikrer, at de unge i praksis forstår de krav, der stilles til arbejdsindsatsens omfang og graden af selvstændigt arbejde, og kan opfylde dem.

2. Computerkompetence: Færdigheder i at bruge computerredskaber på arabisk, herunder både tekstbehandling og internet.

3. Selvevaluering: Evnen til at vurdere egen indsats og resultater, således at de studerende kan evaluere egne færdigheder realistisk

4. Læringsansvar: Evnen til selvstændigt at opstille læringsmål og forfølge dem - det der i pædagogisk terminologi hedder "ansvar for egen læring”. 


\section{Nogle principper}

Hvordan kan e-læring være med til at fremme disse indlæringsmål? Spørgsmålet der er omdrejningspunktet for denne artikel, har som forudsætning at e-læring ikke blot betyder en omlægning af aktiviteter fra det trykte medium til det digitale, men at der i forbindelse med omlægningen er en forventning om, at overførslen til det digitale medium giver en added value, en merværdi, i forhold til at lave samme aktiviteter på traditionel vis.

Der er især tre områder inden for arabiskuddannelsernes eksisterende rammer, som forekommer oplagte at omlægge til e-læring, hvis man ønsker at fremme de ovenfor beskrevne kompetencer: 1. at omlægge de sprogfærdighedstest, der allerede er en del af undervisningsforløbene på 1. og 2. studieår, til online test; 2 . at indføre en anvendelsesorienteret og portfoliobaseret undervisning, i første omgang med henblik på skriftlig produktion; samt 3 . at kombinere den type af evaluering, der løbende foregår af den studerendes indsats i forbindelse med skriftlige opgaver, oplæg m.m., med et betydeligt element at selvevaluering.

I det følgende skal jeg kort gøre rede for baggrunden for og implementeringen af e-læring på disse områder i undervisningsforløbet på 1. studieår. Principperne har dannet grundlag for en ansøgning om e-læringsmidler ved SDU, som er blevet imødekommet, og projektet kører p.t., men er ikke afsluttet. Det betyder i praksis at artiklens sidste del, der drejer sig om, hvordan principperne har fungeret i praksis, primært vil være en beskrivelse af de succeser, problemer og barrierer, vi hidtil har mødt i forløbet, men at der endnu ikke kan konkluderes endeligt på, hvorvidt de kompetencer, vi ønsker at fremme med projektet, reelt også skabes.

\subsection{Fra test til online-test}

Allerede ved oprettelsen af den arabiske cand. negot. uddannelse i 1992 blev der indarbejdet sprogfærdighedstest i de to første studieår. Det var som udgangspunkt inspireret af 1980'ernes proficiency-baserede test i USA, men har tillige det eksplicitte formål at få de studerende til at arbejde kontinuert med sprogtilegnelsen: Erfaringerne fra mange universitetsuddannelser er nemlig, at de studerende har tendens til at skubbe en stor del af pensum foran sig for så at sætte målrettet ind på at læse faget op nogle uger før eksamen.

En sådan studieadfærd er selvsagt ikke velegnet til færdighedsbaseret sprogtilegnelse, så ved at indarbejde 5 obligatoriske test pr. år, som alle skal bestås, for at den studerende kan indstille sig til eksamen, tvinges de studerende til at arbejde langt mere kontinuert med faget. Samtidig gør den systematiske afholdelse af test det muligt at give de studerende løbende feedback på deres niveau og indsats, så de kan måle deres progression, hvilket ofte er en motivationsfremmende faktor. Og studieteknisk har testene tillige eksamensforberedende karakter i den forstand, at eksamen har nogenlunde samme form som testene, hvilket forebygger meget af den usikkerhed og præstationsangst, mange studerende oplever i deres første studieår. Den største ulempe ved obligatoriske sprogfærdighedstest har vist sig at være den megen tid, det tager for underviseren først at udarbejde testene og siden at rette dem.

SDU har valgt at anvende det netbaserede e-læringssystem Blackboard, senest med et tilhørende talemodul fra firmaet Wimba, der gør det muligt for brugerne at kommunikere via voice mails og voice boards. Den anvendte version af Blackboard gør det muligt at bruge arabisk skrift, så længe den computer, der arbejdes på, har installeret de nødvendige tegnsæt og indstillinger - dog kan Blackboards menuer, knapper m.m. kun udformes med latinske bogstaver.

Blackboard har en ganske udbygget testfunktion, dvs. en række prædefinerede skabeloner, der gør det muligt relativt ubesværet at opbygge test baseret på forskelligartede svarmuligheder som true/false, fill in the blanks, essay, jumpled sentences, multiple choice, etc. Og så har Blackboards testfunktion den fordel at de fleste svarmuligheder lader sig rette automatisk, 
eftersom de korrekte svar kan kodes ind i testskabelonen sammen med forskellige feedbackmeldinger, der sammen med det opnåede antal point automatisk meldes tilbage til den studerende.

Det forekom derfor oplagt at overføre de test, vi allerede laver, til online-test på Blackboard: Derved kan vi ikke blot træne de studerende i at skrive arabisk på computer - noget der, som vi skal se nedenfor, har været vanskeligt at få de studerende til - vi vil også kunne integrere nettets arabisksprogede ressourcer i testopgaver med tilhørende informationssøgning, og derved simulere opgaver der i højere grad ligner de krav der i dag stilles i jobfunktioner med arabisk. For den ikke-arabiskkyndige læser kan disse krav måske forekomme indlysende, grænsende til det banale. I praksis betyder den teknologiske udvikling imidlertid, at det først er inden for de seneste 4-5 år, arabisk tekstbehandling er blevet standard på PC, og at websider med arabisk skrift er blevet læsbare for almindelige PC brugere. Både computerteknologien og internettet er "født" med latinske skrifttegn, og de midler, der har været nødvendige for at udvikle teknologien, så den også kan bruges med andre skrifttegn, har typisk været brugt på mere dynamiske områder som det japanske og kinesiske. Det teknologiske efterslæb kan stadig mærkes på både softwareudbud og på de forventninger og færdigheder, vores studerende har hhv. til og i at anvende computerredskaber på arabisk.

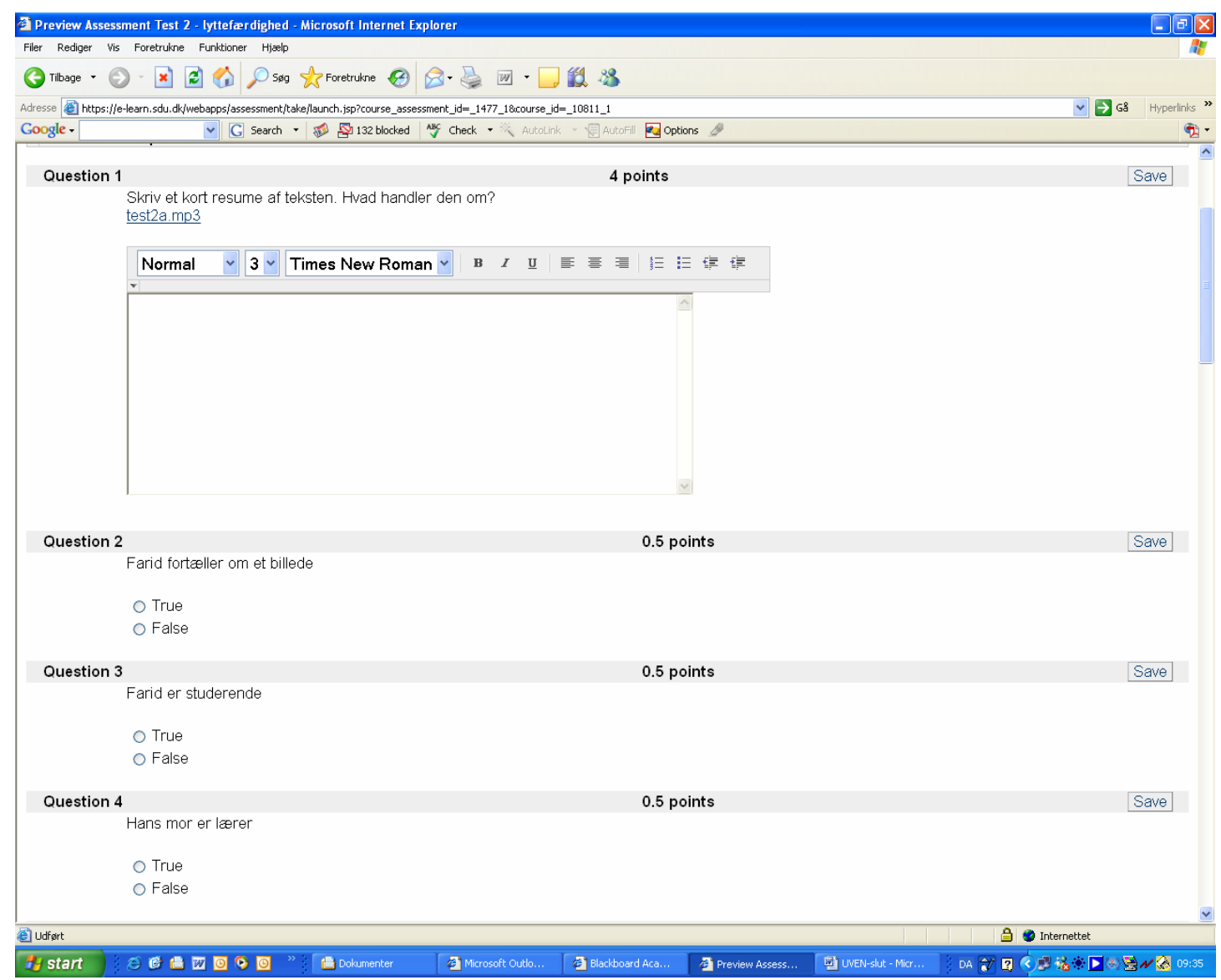

Fig. 1: Eksempel på test i lyttefcrdighed 


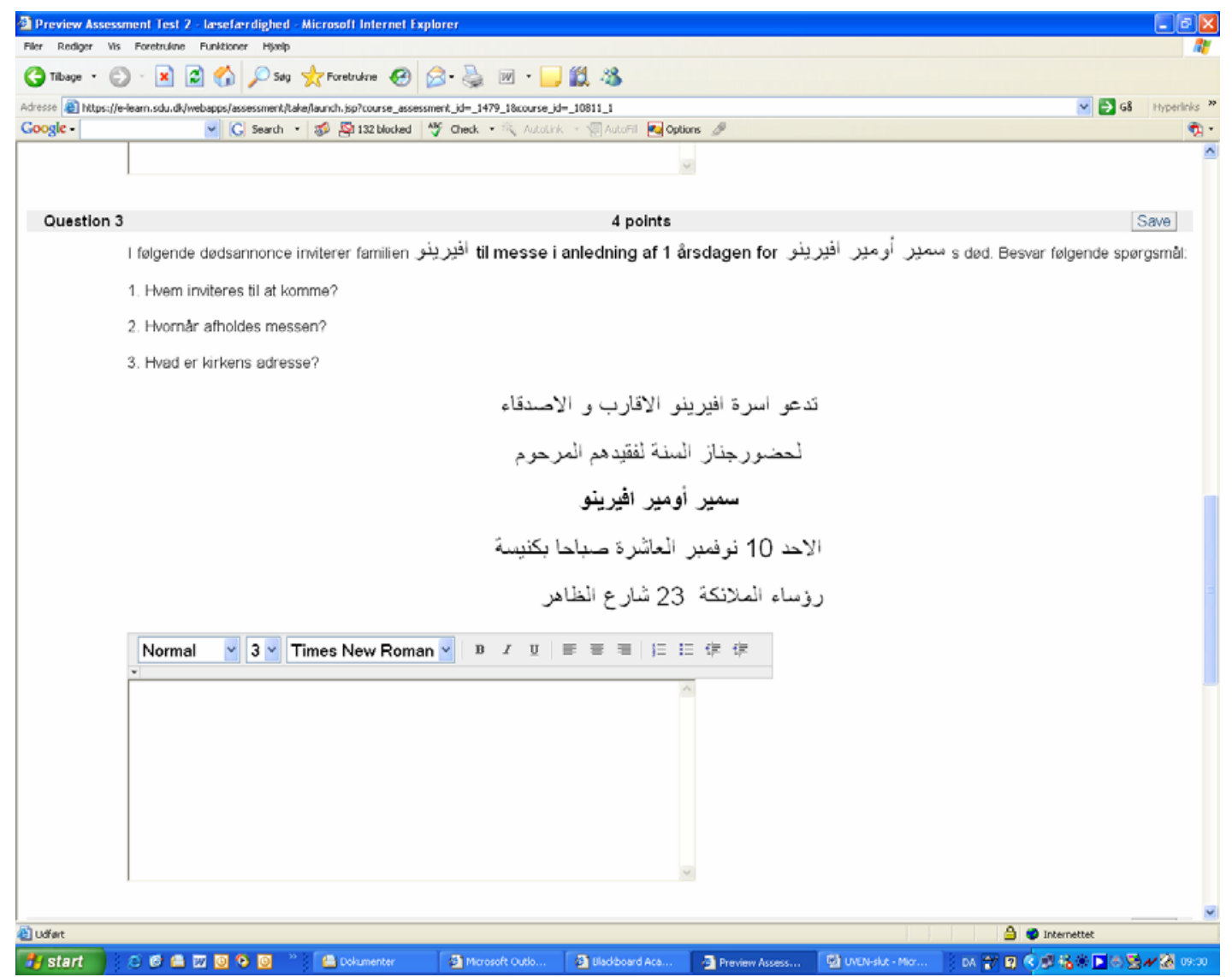

Fig 2. Eksempel på test i læesefcrdighed

\subsection{Fra opgaver til portfolio}

En stor del af den læring, der foregår i skrive- og læsefærdighed i fremmedsprogsfagene, sker i et samarbejde mellem underviseren og den enkelte studerende. Det er en hyppigt anvendt fremgangsmåde, at underviseren på basis af et oplæg eller en tekst beder de studerende skrive en given opgave, som underviseren derefter retter og leverer retur til den studerende med skriftlige eller mundtlige kommentarer, evt. kombineret med en fælles gennemgang af mere generelle problemstillinger i den skriftlige produktion. Især i begynderundervisningen har en stor del af disse opgaver karakter af at træne bestemte sproglige fænomener i enkeltstående sætninger, hvis indhold ikke spiller nogen væsentlig rolle.

At skriftlig læring primært foregår i et samspil mellem underviser og den enkelte studerende kan i hvert fald i begynderundervisningen delvis begrundes med den manglende indholdsdimension - andre studerende får ikke meget ud af at læse standardiserede sætninger og småopgaver. Hvis man imidlertid begynder at tænke skrivefærdighed i mere anvendelsesorienterede produkter som små reklameslogans, billedtekster, postkort, præsentationer af familie, websider etc. - altså noget, der skal skrives til andre end underviseren og "fru universitet" - åbner der sig en hel ny dimension i færdighedstræningen: Så begynder modtageren at få betydning, og de skriftlige produkter bliver interessante for andre at læse, kommentere og diskutere.

Derved opstår et fælles læringsrum, der ikke blot inddrager de medstuderende, men potentielt også alle mulige andre modtagere uden for universitetet. Dette kombineret med de mange muligheder for gratis og ucensurerede publikationsmuligheder på nettet, må formodes at være motiverende for en stor del af de studerende, der nu i en hel anden grad kan se et formål med deres indsats.

Blackboard er meget velegnet som ramme for det læringsrum, der kan skabes ved at lave produktorienteret skriveundervisning: Systemets kommunikationsdel gør det muligt for den studerende ubesværet at korrespondere med underviseren og medstuderende, både mundtligt og 
skriftligt, udveksle dokumenter, inddrage materialer fra nettet og fremvise sine produkter via mailfunktioner, gruppemapper med begrænset brugeradgang, fælles opslagstavler og forskellige emnesites, som alle brugere har adgang til. Og dette læringsrum fremmer ikke kun de studerendes motivation og læsefærdighed, i og med at de kan læse hinandens tekster, men kan også bidrage til en refleksion over egen læring. Det gøres mest systematisk ved at oprette arbejds- og præsentationsportfolier, der jo i bund og grund ikke er andet end to elektroniske mapper, hvori den studerende placerer sine skriveopgaver, evt. i flere versioner, for at illustrere skriveprocessen og siden udvælger et antal produkter, som skal præsenteres for andre end underviseren. Der kan, måske især på de højere sprogfærdighedsniveauer, med fordel knyttes et krav om anvendelse til produkterne i præsentationsfolderen: Postkort kan sendes til udvalgte modtagere, reklameslogans kan publiceres på digitale opslagstavler, madopskrifter kan samles i digitale kogebøger, læserbreve kan sendes til aviser etc. Derved synliggøres anvendeligheden af de studerendes produkter, og de kan samtidig være til gensidig inspiration for de studerende.

\subsection{Fra evaluering til selvevaluering}

Hvis der ses bort fra eksamen, foregår evalueringen af studerendes sprogfærdighed typisk ved, at underviseren løbende retter og kommenterer mundtlige og skriftlige opgaver, som den studerende så kan, men ikke behøver, forholde sig til. Sådan har det også været på vores arabiskuddannelser: Evalueringen er typisk foregået i forbindelse med traditionel opgaveskrivning og de omtalte sprogfærdighedstest, hvor de studerende efter hver test har fået en tilbagemelding på deres resultater i form af et antal point samt evt. kommentarer til fejl og mangler.

På basis heraf har underviseren så en forventning om at den studerende selv arbejder videre med det eller de områder, der måtte være nødvendige for at opnå en bedre sprogfærdighed. Der har ikke været procedurer, som sikrer at den studerende arbejder systematisk og sammenhængende med sine resultater, eller at testresultaterne bindes sammen i et sammenhængende læringsforløb; hvad de studerende stiller op med deres resultater, og hvordan det påvirker deres egen vurdering af sprogfærdigheden, er med andre ord ganske deres egen sag. Her bør det tilføjes at anvendelse af portfolio i undervisningen i den henseende ikke adskiller sig fra traditionel opgaveskrivning og test, for portfolio er i sig selv heller ikke nogen garanti for at den evaluering underviseren fremkommer med, fører til yderligere selvrefleksion eller en mere realistisk vurdering af egen sprogfærdighed.

Behovet for realistisk selvevaluering er blevet særligt tydeligt i en sammenhæng, som i disse år muligvis er særegen for arabiskuddannelserne. I takt med, at vi har fået stadig flere studerende med arabisk baggrund, som har en eller anden grad af sproglige forudsætninger, har vi kunnet konstatere at en del unge har tendens til at overvurdere deres arabiskfærdigheder. Når nye studerende anfører at de har arabiske sprogkundskaber, tester vi dem ved studiestart, så de evt. kan fritages for dele af undervisningen og bruge deres kræfter på andre dele af uddannelsen.

Mange af de unge går som hovedregel ud fra at de kan bestå testene uden problemer, men her får en del af dem sig en stor overraskelse: Som tommelfingerregel har det været ca. halvdelen af dem, der blev testet - og som altså mente at kunne så meget arabisk at de kunne bestå den eksamen, som danskere uden forudsætninger i arabisk skal bestå efter første studieår - der klarede 1. årsprøve, og igen halvdelen af disse, som klarede 2. årsprøve. Eller sagt på en anden måde: Halvdelen af dem, der mente at beherske arabisk ved studiestart, kunne altså ikke så meget sprog, at de kunne bestå 1. års-prøve for danskere. Og det tal bliver stadig større: I 2005 var det $75 \%$ af de studerende med arabisk baggrund, der ikke klarede 1. årsprøve ved studiestart. Mange af de unge tror altså, at de behersker arabisk bedre, end de reelt gør, og et 
sådant fejlskøn er ikke uden betydning - hverken i uddannelsessammenhæng, hvor de unge oplever, at der sættes spørgsmål ved deres identitet ${ }^{3}$, eller i en potentiel arbejdsmarkedssituation, hvor det kan få store konsekvenser både for de unge og for en eventuel arbejdsgiver, hvis de ikke kan leve op til de forventninger, de selv har skabt.

For at træne de studerende i at vurdere deres sprogfærdighed i arabisk, så de får et realistisk billede af deres kompetencer, og kan vurdere, hvor de mest hensigtsmæssigt bør lægge deres arbejdsindsats, har vi indført nogle procedurer og krav i forbindelse med online-test og portfolio, der skal fremme denne selvevaluering: Når online-testen er rettet, får de studerende en elektronisk kopi af deres opgaver og skal i forlængelse heraf udfylde et elektronisk spørgeskema, hvori de skal vurdere deres resultat, indkredse eventuelle problemer og sammenholde det med deres arbejdsindsats. De bliver også bedt om at formulere, hvad de selv mener de bør gøre i forløbet frem til næste test for at forbedre deres resultater, og først når denne selvevaluering er udfyldt, godskrives testen officielt.

På basis af testresultat og selvevalueringen udarbejder underviseren så en læringsplan, som lægges ind i den studerendes arbejdsportfolio, hvortil kun underviseren og den studerende har adgang. Den studerende skal så godkende og/eller diskutere denne læringsplan, der har til formål at danne grundlag for den studerendes selvstændige arbejde frem mod næste test. Ideen er med andre ord at binde de enkeltstående test sammen til et læringsforløb, der suppleret med kommentarer fra den daglige undervisning gør det transparent for den studerende, hvilken indsats der er nødvendig for at forbedre sprogfærdigheden, og hvor den mest hensigtsmæssigt skal lægges. Forløbet er tilrettelagt, så begge aktører - både den studerende og underviseren - får mulighed for at formulere deres syn på sagen, så eventuelle misforhold kan indkredses og diskuteres.

Selvevalueringsprocessen, der altså konstrueres i fællesskab af den enkelte studerende og underviseren, foregår ved hjælp af Blackboards gruppesider: Her oprettes et diskussionsforum med adgang for de involverede aktører, og læringsplanerne opbygges efter et system, som kan ses af nedenstående skærmbillede:

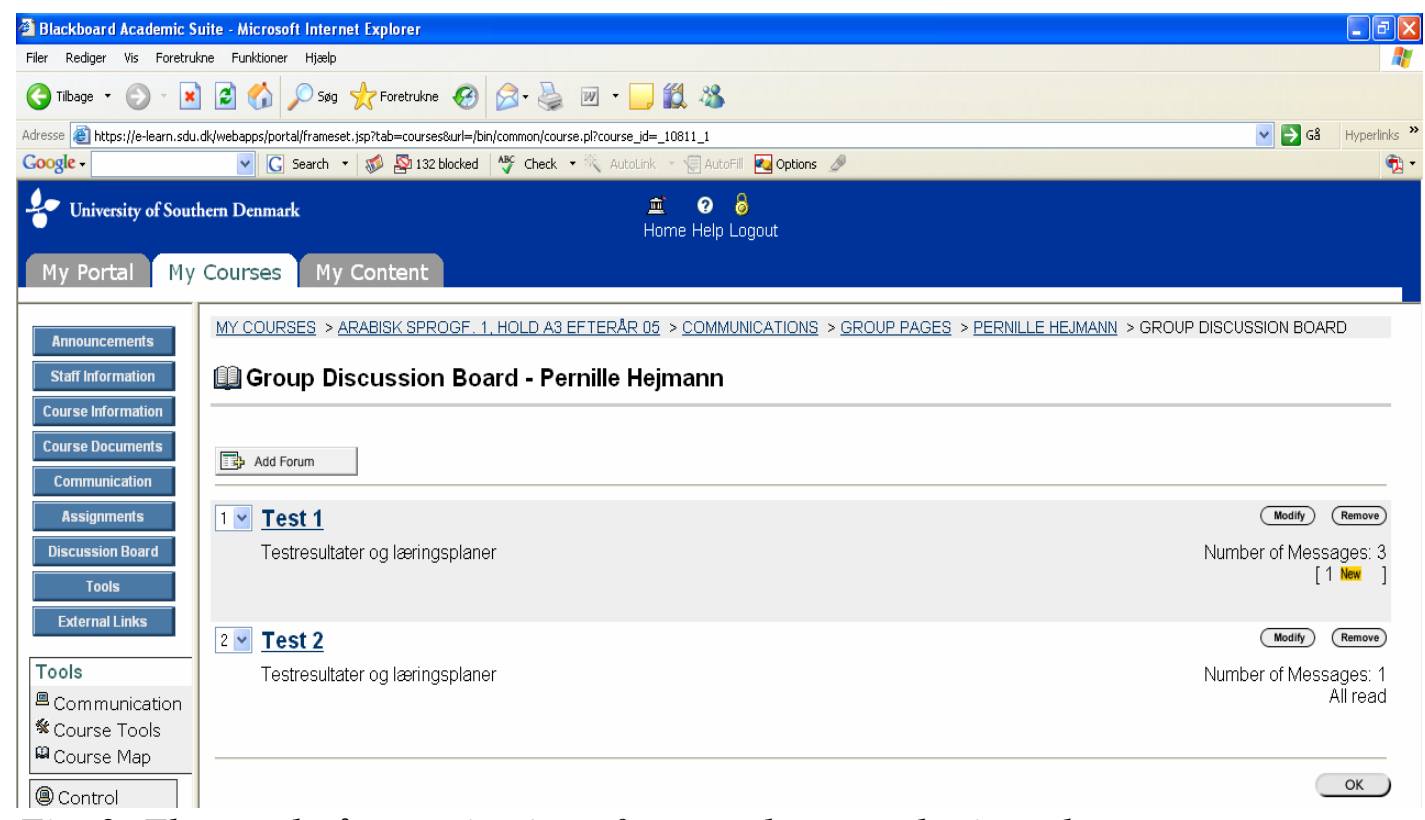

Fig. 3: Eksempel på organisering af testresultater og laringsplaner 


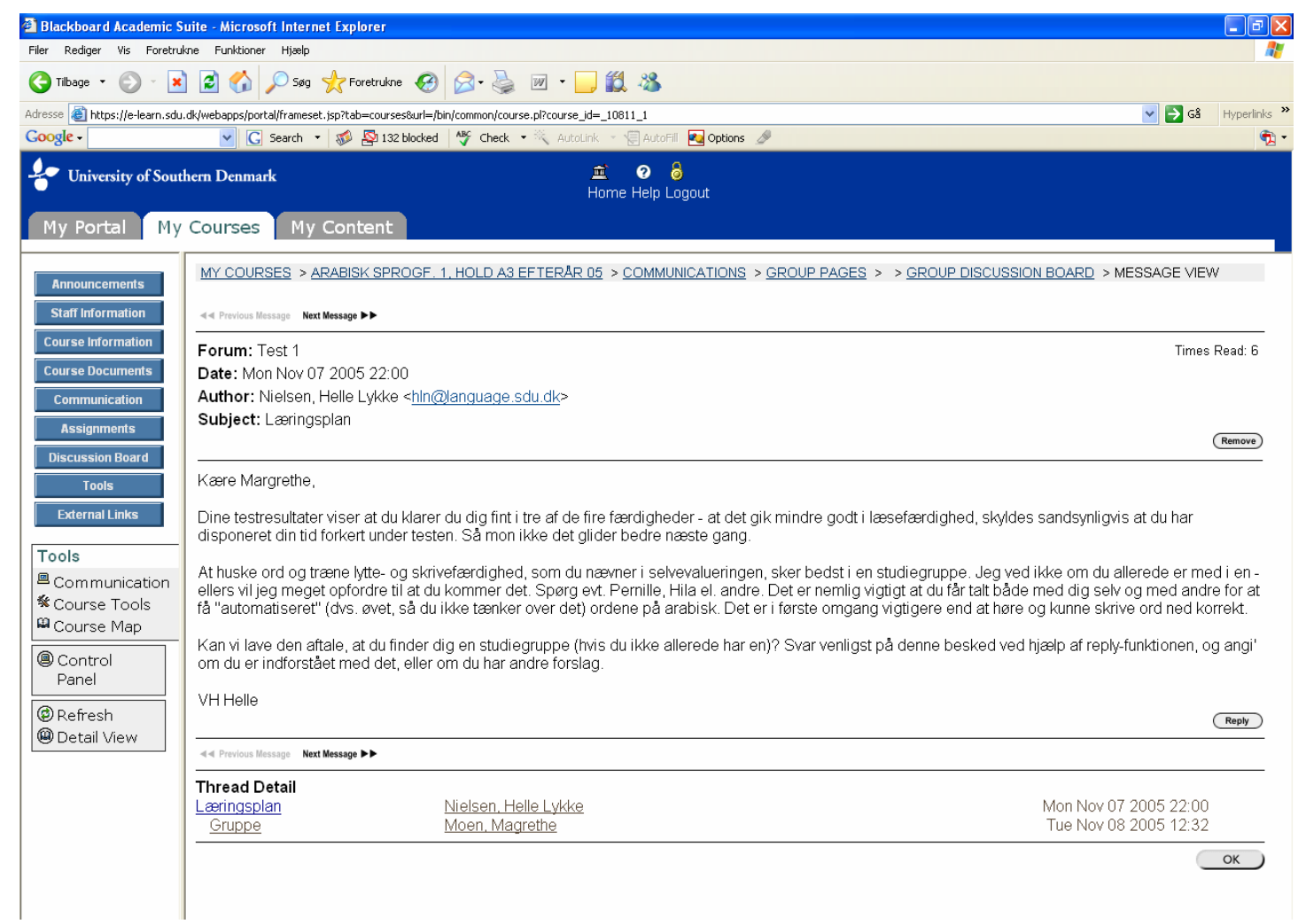

Fig. 4: Eksempel på lceringsplan

Med baggrund i læringsplanernes indhold har vi valgt ikke at inddrage medstuderendes kommentarer og kritik - dertil er læringsplanerne for personlige. Men skulle man ønske det, er det blot et spørgsmål om at give flere brugere adgang til det oprettede diskussionsforum.

Et andet værktøj, vi har taget i brug til selvevaluering, er European Language Passport, der er en del af Common European Framework of Reference for Languages. Det er et standardiseret selvevalueringsværktøj i form af skemaer med beskrivelser af forskellige sprogfærdighedsniveauer for både tale-, lytte-, læse- og skrivefærdighed. Værktøjet, der kan anvendes til alle sprog, er udarbejdet med det formål at skabe en standardiseret beskrivelse af sprogfærdighedsniveauer, der ikke tager hensyn til nationale karaktersystemer, og som tillige beskriver sprogfærdighed i konkrete sproghandlinger og derved giver en vurdering af, hvad den enkelte kan udrette på målsproget. Det gør det anvendeligt i både pædagogisk og professionel sammenhæng: De studerende kan måle deres færdigheder med andre studerendes på tværs af grænser og sammenligne deres kompetencer i arabisk med andre fremmedsprog, ligesom de kan bruge det til at skabe kontinuitet ved skift til nyt studiested. Sidstnævnte er relevant for vores uddannelser, eftersom de studerende skal tilbringe 3. studieår ved en uddannelsesinstitution i et arabisktalende land: Ved at lægge det europæiske sprogpas ind i den studerendes fremvisningsportfolio, som sendes til det arabiske studiested før studiestart, gives der gode muligheder for at skabe kontinuitet i den studerendes studieforløb. Og så er sprogpasset særlig brugbart inden for fjerne fremmedsprog som arabisk, når der skal søges job, for de fleste danske og europæiske arbejdsgivere har svært ved at evaluere ansøgeres reelle sprogkompetencer på egen hånd, også selvom der foreligger eksamensbeviser, der med tal angiver resultatet af flere sprogfag.

I forbindelse med 1. studieår, der jo er i fokus her, anvendes skemaet ved studiestart, primært for de studerende, der har forkundskaber i arabisk, så det kan bruges som sammenligning med det resultat, de unge opnår ved studiestartstesten. Viser sammenligningen, at de har vurderet deres færdigheder realistisk, får de blot den melding, at de skal stille til en lignende test i sprogfærdighed 2 ved næste studieårs begyndelse. Er der derimod stor diskrepans mellem 
selvevalueringen og det konkrete testresultat, giver sammenligningen basis for en indsigt, som den studerende er nødt til at forholde sig til i sit videre studieforløb.

For de øvrige studerende skal sprogpasset anvendes i forlængelse af de selvevalueringer, der følger efter hver test, således at det udleveres før 1. årsprøve, dvs. efter 5 selvevalueringer, og derefter sammenlignes med eksamensresultatet. De studerendes kompetencer til selvevaluering skal derefter sammenlignes med en kontrolgruppe af studerende, der også udfylder sprogpasset, men ikke har trænet selvevaluering i løbet af året.

\subsection{Merværdi ved brug af Blackboard}

Alle beskrevne processer, både ved online-test, portfolio, evalueringer og selvevalueringer, foregår ved brug af Blackboard, og har altså form af e-læring. Det har en lang række fordele, som berører de kompetencer, vi gerne vil udvikle i arabiskuddannelserne: Dels fremmer det pr. automatik de studerendes computerkompetencer på arabisk, dels muliggør det, at de studerende kan arbejde struktureret med dele af uddannelsen uden for undervisningen og dermed træne deres studiekompetencer (og på lidt længere sigt deres læringskompetencer). Placeringen på Blackboard betyder endvidere, at der skabes rammer for et integreret læringsrum, hvor den studerende har adgang til at kommunikere, hente og producere materialer, distribuere dem til udvalgte modtagere, diskutere dem og modtage feed-back. Læringsrummet er med andre ord interaktivt og fleksibelt og alligevel afgrænset på en hel anden måde, end det ville have været, hvis man havde valgt at arbejde med de beskrevne processer ved hjælp af trykt materiale, papirmapper og konkret udveksling af materialer.

Ved yderligere at integrere processer, der sikrer selvevaluering, får den studerende også tid til at reflektere over egne tilegnelsesprocesser på en hel anden måde, end den umiddelbare, ofte mundtlige feedback fra en underviser kan afføde.

Det faktum at det samlede læringsrum gør det muligt at integrere flere processer i et samlende medium, gør det lettere for de studerende at overskue forløbet og dermed på sigt at opøve et læringsansvar, som ikke blot vil komme dem til gode i studiemæssig sammenhæng, men også på et omskifteligt akademisk arbejdsmarked.

\section{Praksisrelaterede problemer}

På nuværende tidspunkt har vi implementeret de første online test med tilhørende selvevaluering og læringsplaner, lavet opgaver, der skal lægges i en arbejdsportfolio, samt anvendt det europæiske sprogpas for de studerende, der er blevet testet ved studiestart med henblik på at vurdere deres kompetencer i arabisk. I det følgende skal jeg beskrive de erfaringer, vi hidtil har gjort med hensyn til brug af teknologien, de studerendes reaktioner på brug af online test, udarbejdelse og brug af læringsplaner og til slut give en foreløbig vurdering af projektets anvendelighed.

\subsection{Den uvante teknologi}

I praksis er det brug af teknologien, dvs. opkobling til og brug af Blackboard, samt det at få de studerendes egne computere til at skrive arabisk, der har taget mest tid og opmærksomhed i forløbet. Småproblemer som at huske det password, de studerende har fået tildelt af universitetet, logge korrekt ind på universitetets computere og vælge korrekte stier af links til et givet materiale, gjorde det på et meget tidligt tidspunkt klart, at det var nødvendigt dels at lave entydige skriftlige instruktioner for, hvordan de dele af systemet, vi skal bruge, fungerer, dels at tilskrive de studerende et klart afgrænset ansvar for bestemte procedurer, så der ikke skulle gå unødig undervisningstid til spilde.

På basis af de udleverede instruktioner forekom det alle - også de studerende, der beklagede sig over besværet og de mærkelige krumspring, de mente computerne foretog - acceptabelt, at 
det teknologiske udgangspunkt i undervisningen og følgelig også ved online test var at sidde klar ved en opkoblet computer, der kunne skrive arabisk, når undervisningen eller testen tog sin begyndelse. Småproblemerne gjorde det endvidere tydeligt, at det i tilfælde, hvor der var et valg mellem flere forskellige teknologiske muligheder, til enhver tid gjaldt om at vælge den mindst komplicerede løsning. Det var fx grunden til at læringsplanerne blev oprettet som gruppebaserede diskussionsfora, der kun kræver enkelte klik for at fungere, frem for at etablere dem i det, der i Blackboards terminologi hedder content-systemet, som ville have været mere velegnet pga. flere hensigtsmæssige funktioner, men også mere kompliceret i brug.

Det har i den forbindelse været interessant at se, hvordan de studerende har håndteret kravet om at skrive arabisk på computer. Det er i dag muligt at skrive arabisk i Word, hvis blot styresystemet er installeret med de rette sprogindstillinger - det eneste, man i praksis skal foretage sig, er at skifte sprog på en lille sprogikon i bundlinien samt ændre styresystemets skriveretning ved at klikke på en ikon i topmenuen. De studerende fik en introduktion til dette på universitetets computere samt en tydelig instruktion om, hvordan de kan indstille deres egen computer til at skrive arabisk, og derefter blev de i en periode på 3 uger bedt om løbende at aflevere opgaver, der var skrevet ind i Word - alt sammen som en optakt til deres første online-test.

Det var imidlertid kun meget få af de studerende, primært de etnisk-danske, der fulgte opfordringen - resten havde alle mulige begrundelser for at lade være, lige fra at de ikke kunne få deres egne computere til at skrive arabisk, og at universitetets var optaget, til at det var meget vigtigt at have en god håndskrift på arabisk, og at arabere alligevel ikke brugte computere. Antagelsen om, at de studerende uden videre kunne eller ville overføre deres computermæssige færdigheder i noget så grundlæggende som brug af tekstbehandlingsprogram til arabisk, holdt med andre ord ikke, og var disse indvendinger på det tidspunkt, ca. 1 måned inde i studieforløbet, blevet taget alvorligt, havde det været umuligt at gennemføre projektet.

Vi valgte i stedet at meddele de studerende, at det selvfølgelig var frivilligt at aflevere opgaver indskrevet på computer, men at den kommende test ville foregå på computer, hvad enten de havde øvet sig eller ej, først og fremmest fordi vi mente, at det var uforsvarligt at uddanne universitetskandidater i arabisk, der ikke havde grundlæggende computerfærdigheder, for uden disse ville de ikke kunne fungere på arbejdsmarkedet.

Lette teknologiske løsninger, klare detaljerede instruktioner og argumenter, der tydeliggør begrundelsen for overhovedet at tilegne sig computerkompetencer på arabisk, var med andre ord nødvendige forudsætninger for overhovedet at få omlægningen af vores sprogfærdighedstest til Blackboard til at fungere. Alligevel brød de studerende sig ikke meget om det, og argumenterede ved enhver given lejlighed for en udsættelse af online test, og de blev ikke mildere stemt efter at have fået deres resultater fra den første test. Mange havde nemlig præsteret så dårlige resultater i skrivefærdighed, at de simpelthen ikke kunne bestå (noget vi siden har valgt at løse ved at stille nogle opgaver, der træner skrivefærdighed, og siden lade dem tage en lignende test igen). Bedre blev stemningen ikke ved den følgende online test, der fandt sted i ugen op til jul. Her var flere allerede på vej hjem på ferie til både Libanon, Norge og rundt om i Danmark, og det blev derfor besluttet at de studerende denne gang måtte tage testen fra en computer efter eget valg - på universitetet, hjemme eller hvor de nu befandt sig i verden trods mulighederne for at inddrage hjælpemidler som ikke er tilladt, men som altså ikke lader sig kontrollere. Her gik det hverken værre eller bedre end at det centrale Blackboard-system gik ned 2 timer, før testen skulle afholdes, og først kom i gang 4-5 timer senere. Det affødte kaotiske tilstande, for det var ikke muligt at komme i kontakt med de studerende, der jo var spredt rundt om i Danmark og resten af verden, bl.a. fordi alle e-mailadresser, telefonnumre m.m. lå i det system, der var gået ned. Samtidig havde hverken studieledere, teknikere eller 
folk i e-læringsorganisationen noget bud på, hvordan en sådan situation skal håndteres formelt.

Efter nogle kaotiske timer lykkedes det dog at få kommunikeret ud til de fleste at testen ville blive afholdt dagen efter, og da den endeligt fandt sted, fungerede teknikken upåklageligt blot var der flere, som ikke var blevet orienteret, og derfor måtte tage testen på et senere tidspunkt. Også strømafbrydelser som jo er almindelige i Mellemøsten, gav problemer, for her måtte en studerende igennem samme test tre gange, før det lykkedes at indlevere den digitalt.

Det er derfor ikke underligt at en god del af de studerende på nuværende tidspunkt er utilfredse med online test i skrivefærdighed, mens online test i lytte- og læsefærdighed er relativt uproblematiske. ${ }^{4}$ Til gengæld har processen gjort det entydigt klart for de studerende at de er nødt til at træne deres skrivefærdighed i arabisk på computer, hvad enten de bryder sig om det eller ej - en erkendelse, vi næppe havde nået ad frivillighedens vej, sådan som vi indledningsvist forsøgte.

\subsection{Udarbejdelse og brug af læringsplaner}

Alle test skal som nævnt ovenfor følges op af en selvevaluering der skal udfyldes, før testen kan godskrives. Testresultatet danner så sammen med selvevalueringen baggrund for den læringsplan, underviseren foreslår, og som derefter enten accepteres af eller diskuteres og revideres i samarbejde med den studerende. Målet er, at der foreligger en eksplicit læringsplan, som kan binde de enkelte testresultater sammen i et samlet læringsforløb og som, hvis den følges, formodes at kunne kvalificere den studerendes arbejde med sprogtilegnelsen. Derved trænes både studiekompetencen og siden også den studerendes læringsansvar.

Også her har det været interessant at notere sig, hvordan de studerende bruger dette værktøj. Holdet der består af 24 studerende, har en kønsmæssig fordeling på 6 drenge og 18 piger. Etnisk fordeler holdet sig på 4 etniske danskere (alle piger), 1 nordmand (pige), 1 somalier (dreng), mens resten har mellemøstlig baggrund, dvs. enten er født i Danmark af forældre med mellemøstlig baggrund (arabisk, kurdisk, tyrkisk, afghansk, iransk), eller er kommet til Danmark som børn eller relativt unge. Kun en enkelt er kommet hertil som voksen flygtning.

Af de 24 læringsplaner, som hidtil er blevet udarbejdet pr. test, har 8 studerende læst og konfirmeret deres læringsplaner, 8 andre studerende har læst - eller i hvert fald åbnet - læringsplanerne, men hverken konfirmeret eller ønsket at diskutere dem, mens de sidste 8 slet ikke har åbnet dem og altså ikke ved, hvad de indeholder. Denne fordeling har et kønsmæssigt aspekt: Alle 8 studerende der har reageret på læringsplanen, er piger, mens 5 af de 8 studerende der end ikke har åbnet planerne, er drenge. Kun en af holdets 6 drenge har åbnet sin læringsplan, men altså ikke reageret. Ser vi på den etniske fordeling, finder vi alle 4 danske og den enlige norske studerende i den gruppe, der har bekræftet læringsplanerne. Interessant er det også at notere sig, at 6 af de 8 studerende, der har valgt at bekræfte læringsplanerne, må betegnes som studievante, aktive og dygtige studerende, der i forvejen arbejder systematisk og godt med sprogtilegnelsen, mens der blandt de studerende, der end ikke har åbnet studieplanerne, findes studerende, der i første omgang er dumpet i både første og anden test.

\section{Tentative konklusioner}

Der kan på det foreliggende grundlag uddrages tre tentative konklusioner om brugen af elæring: For det første ser det ud til at e-læringsredskaber skal være obligatoriske, sådan som det er tilfældet med brug af arabisk tekstbehandling, online test og selvevalueringer, før man kan regne med, at alle studerende vil bruge dem. Er brugen af værktøjer ikke obligatorisk, som i tilfældet med læringsplanerne, er responsen relativt lav. 
For det andet er der noget der kan tyde på, at læringsstil følger de studerendes etniske baggrund - ikke sådan at forstå at etnicitet i biologisk forstand spiller nogen rolle for tilegnelsen, men at unge der er socialiseret ind i autoritære opdragelses- og læringsmønstre, som stadig er hyppigt forekommende i mellemøstlige familier, også selvom disse befinder sig uden for det geografiske Mellemøsten, muligvis har svært ved at se relevansen af en mere flad og fleksibel læringsmodel, der postulerer nytte ved at tage ansvar for egen læring. En sådan forklaringsmodel er selvsagt meget tentativ og bør underkastes nøjere granskning.

Og som det tredje tyder de foreløbige resultater fra projektet på at e-læringsværktøjer langt hen ad vejen ser ud til at støtte de studerende, der i forvejen klarer sig godt studieteknisk og læringsmæssigt, mens de svage studerende, der kunne have god brug for at træne deres studieog læringskompetencer, ikke ser ud til at anvende dem. Derved uddyber brugen af e-læring i virkeligheden den kløft mellem gode og mindre gode studerende, som den netop var sat i søen for at mindske, i hvert fald i dette projekt. Denne konklusion støttes af andre resultater (se Nielsen, 2005) og giver god grund til at reflektere over, hvordan vi i fremtiden bedre kan hjælpe de studerende, der reelt har brug for at forbedre deres studiekompetencer og sprogfærdighed.

\section{Referencer:}

Common European Framework of Reference for languages (http://www.culture2.coe.int/portfolio/documents_intro/common_framework.html).

\section{European Language Passport (http://europass.cedefop.eu.int)}

Helle Lykke Nielsen: Kulturmøder i uddannelserne - hvor svært kan det være? I: SocialXpress, no. 3, 2006 (in press)

Helle Lykke Nielsen, Gunna Funder Hansen og Maria Kyung Overgaard: Al-Maqha: A lowtech web cafe for foreign language learners, i: The JALT CALL journal, vol. 1, no. 2, September 2005. pp. 75 - 86

\footnotetext{
1 På Syddansk Universitet kan man også læse arabisk sidefag, både som dagstudium, der kombineres med et andet humanistisk fag, og på deltid via åben uddannelse.

${ }^{2}$ For en begrundelse for denne gruppes særlige behov i universitetsuddannelserne, se Nielsen 2006.

${ }^{3}$ For en forklaring af dette, se Nielsen 2006.

${ }^{4}$ Mundtlig sprogfærdighed er endnu ikke integreret i online test, men foregår stadig i et sproglaboratorium.
} 